\title{
CORN DISTILLER'S DRIED GRAINS WITH SOLUBLES: APPARENT DIGESTIBILITY AND DIGESTIVE ENZYMES ACTIVITIES IN EUROPEAN SEABASS (Dicentrarchus labrax) AND MEAGRE (Argyrosomus regius)
}

Rui Magalhães ${ }^{1,2^{*}}$, Filipe Coutinho ${ }^{1,2}$, Pedro Pousão ${ }^{3}$, Tiago Aires ${ }^{4}$, Aires Oliva-Teles ${ }^{1,2}$, Helena Peres $^{1,2}$

${ }^{1}$ CIMAR/CIIMAR - Centro Interdisciplinar de Investigação Marinha e Ambiental, Universidade do Porto, Rua dos Bragas 289, 4050-123 Porto, Portugal

${ }^{2}$ Departamento de Biologia, Faculdade de Ciências, Universidade do Porto, Rua do Campo Alegre, Edifício FC4, 4169-007 Porto, Portugal

${ }^{3}$ Instituto Português do Mar e da Atmosfera (IPMA), Av. 5 de Outubro, Olhão, Portugal

${ }^{4}$ Aquasoja, Soja de Portugal, S.A

*Corresponding author: Departamento de Biologia, Faculdade de Ciências da Universidade do Porto, Rua do Campo Alegre, Edifício FC4, 4169-007 Porto, Portugal

Tel.:+351 22340 1507; Fax: +351 22340 1511. E-mail address: rui_pedro10@hotmail.com (Rui Magalhães) 


\section{Abstract}

Corn distillers dried grains with solubles (DDGS) is a co-product of corn ethanol production which biological value is dependent on technological processes and so may be highly variable among production plants. Therefore, two digestibility trials were conducted to evaluate the apparent digestibility coefficients (ADCs) of nutrients and energy of two commercial sources of DDGS and their effects on digestive enzyme activities in European seabass and meagre juveniles. DDGS digestibility was determined based on the substitution of $30 \%$ of a reference diet $(45 \% \mathrm{CP} ; 16 \% \mathrm{CL})$ by each test DDGS.

ADCs of protein (92-98\%), most amino acids (75-99\%) and lipids (82-89\%) were high while that of energy (58-68\%) was low, reflecting the high indigestible fiber content of DDGS. ADCS of nutrients and energy of DDGS were similar in both species, except for some amino acids (lysine, arginine, histidine, isoleucine, tyrosine and aspartic acid) which were higher for seabass than for meagre. Independent of fish species, ADCs of protein and energy were higher in $D D G S_{1}$ than in $D D G S_{2}$, whereas $A D C s$ of lipids and most amino acid were not affected by DDGS source.

Digestive enzymes activities were species specific: protease activity was higher in meagre while lipase and amylase activities were higher in seabass. For both species, all digestive enzymes activities were higher in mid intestine than in anterior or distal intestine.

Overall, it is concluded that corn DDGS is well digested and seem to have high potential for inclusion in diets for seabass and meagre juveniles.

Keywords: Distillers dried grains with solubles (DDGS); seabass; meagre; digestibility; digestive enzymes. 


\section{Introduction}

Aquaculture production is growing up to fill the increasing demand of fish for human consumption. Intensive aquaculture production of fish, particularly carnivorous fish, is still based on high quality fish meal and fish oil. Nevertheless the use of these commodities in aquafeeds has been decreasing (Karapanagiotidis, 2014), due to a higher demand of fisheries products, world limited availability, market supply fluctuations and raising prices, which have stimulated research on the use of more sustainable alternative feedstuffs (Gatlin et al., 2007).

Distiller's dried grains with solubles (DDGS) are the dry residue that remains after fermentation of cereal grain mash by selected enzymes and yeast to produce ethanol and carbon dioxide, and its availability as a feed ingredient is increasing with the increase of biofuel industry (Li et al., 2011; Brown et al., 2012; Liu, 2012). As availability increases, price of distiller grain by-products becomes more competitive and this has enhanced its use in animal feeds (Renewable Fuels Association, 2013).

DDGS protein content ranges from 26 to 33\%, fat from 9 to 14\%, neutral detergent fiber from 33 to 44\% (Liu, 2012). DDGS is almost devoid of starch which was fermented by yeast to produce ethanol. DDGS nutrient composition, except starch, is approximately three to four-fold higher than those in the original grain due to the fermentation process, and has an amino acid profile similar to that of whole grain (Stein, 2007; Brown et al., 2012). Although DDGS contains a high content of non-starch polysaccharides, it lacks other common antinutritional factors that are usually found in other plant feedstuffs, namely trypsin inhibitor, gossypol, glucosinolates, erucic acid and has low levels of phytate, being a good source of vitamins and palatable to fish (Hertrampf and Piedad-Pascal, 2000; Lim et al., 2011; Brown et al., 2012; Overland et al., 2013). DDGS also contains substantial amounts of yeast cells (Lim et al., 2011), which may contribute to improve fish immune status and disease resistance (Lim et al., 2011; Oliva-Teles, 2012). DDGS also has a very competitive price, comparatively to other plant ingredients, however its relatively high crude fiber level may limit its use in aquafeeds, particularly for carnivorous fish species (Hertrampf and Piedad-Pascal, 2000).

The main problem of using DDGS in feed formulation is the high variability of nutrient concentration among different DDGS sources (Robinson and Li, 2008; Liu, 2012). The 
presence of xanthophylls in corn DDGS can also lead to yellow pigmentation of fillets (Lim et al., 2011). However, ethanol extraction of the lipid fraction may effectively remove most of the yellow pigments in DDGS, thus avoiding the yellow pigment deposition, as it was observed in catfish, Ictalurus punctatus (Li et al., 2011) and hybrid striped bass, Morone chrysops x M. saxatilis, (Trushenski and Gause, 2013).

DDGS has been evaluated as feed ingredient for a few fish, particularly omnivorous species, as it has a protein content close to the requirement of the species (Brown et al., 2012) and because omnivorous fish tolerate higher dietary fiber levels than carnivorous species. In Nile tilapia, Oreochromis niloticus, a series of studies on the use of diets without fish meal showed that corn DDGS can be utilized at considerable high levels (up to 49\%; Wu et al., 1994; 1996; 1997). Abo-State et al. (2009) further observed in this species that DDGS could be included in the diets up to $55 \%$, completely replacing soybean meal, without affecting fish performance. Concomitant dietary lysine supplementation may enable DDGS incorporation up to $60 \%$ without affecting growth performance, immune function or disease resistance of Nile tilapia (Shelby et al., 2008). Similarly, in channel catfish, DDGS can be included in the diets up to $40 \%$ (Tidwell et al., 1990) or to $70 \%$ if diets are supplemented with lysine (Webster et al., 1991) without compromising growth performance and feed utilization. Moreover, in channel catfish diets with 90\% DDGS without lysine supplementation can be used during winter feeding without affecting performance (Webster and Tidwell, 1992). Furthermore, combination of $35 \%$ DDGS and various levels of soybean meal can completely replace dietary fish meal in this species (Webster et al., 1992). However, other studies reported growth depression when dietary fish meal was replaced by corn DDGS in Nile tilapia (Salama et al., 2011). Coyle at al. (2004) also observed in hybrid tilapia (O. niloticus $x$ O. aureus) that diets with $30 \%$ DDGS and without animal protein depressed growth, while with diets including DDGS in combination with meat and bone meal growth performance was similar to the control diet, which included $12 \%$ fish meal.

In rainbow trout (Oncorhynchus mykiss), DDGS can be incorporated in diets at $15 \%$ replacing $50 \%$ of fish meal, or at $22.5 \%$ replacing $75 \%$ of fish meal provided that diets are supplemented with lysine and methionine (Cheng and Hardy, 2004). On the contrary, Stone et al., (2005) concluded that only up to $18 \%$ corn products (10\% DDGS and $8 \%$ corn gluten meal), representing $25 \%$ replacement of dietary fish meal can be included in practical diets. 
The presence of indigestible carbohydrates in DDGS was appointed out as responsible for the limited potential of corn co-products to replace dietary fish meal in trout diets. However, more recently, Overland et al. (2013) concluded that DDGS could efficiently replace up to $100 \%$ of typical plant ingredients mixture (sunflower meal, rapeseed meal and field peas) in diets for rainbow trout, without affecting fish performance. In yellow perch growth performance was not affected by dietary inclusion of up to $40 \%$ DDGS partially replacing soybean meal (Schaeffer et al., 2011). Also in hybrid striped bass the dietary inclusion of 33\% of DDGS did not affect fish performance, feed efficiency, fillet color or consumer acceptance (Trushenski and Gause, 2013).

Though several studies were already performed to evaluate nutritional potential of DDGS in different species, up to now data on corn DDGS digestibility is very scarce. In rainbow trout, apparent digestibility coefficients (ADCs) of protein (88-90\%) and lipids (79-89\%) is high, but that of dry matter (47-59\%) and energy (50-67\%) is much lower, reflecting the high indigestible carbohydrate content of DDGS (Cheng and Hardy, 2004). In hybrid striped bass, however, DDGS protein, lipids and dry matter digestibility are much lower (65\%,69\% and 10\%, respectively; Thompson et al., 2008). Thus, ADCs of DDGS seems to be dependent on the digestive capacity of the fish species, particularly in which concerns the digestion of nonprotein energy fraction that is higher in fish with lower trophic level (Castro et al., 2013).

European seabass, Dicentrarchus labrax, is a well-established aquaculture species in the Mediterranean, and meagre, Argyrosomus regius, is considered one of the most promising species for Mediterranean aquaculture diversification. As rationale aquafeed formulation requires an evaluation of ingredient digestibility, the objective of the present study was to evaluate the nutrient digestibility of two corn DDGS products commercially available in the European market. Further, as dietary DDGS may interfere with enzyme activity, digestive enzyme activities in fish fed DDGS including diets was also studied.

\section{Materials and methods}

\subsection{Experimental diets}


A reference diet was formulated to contain $45 \%$ protein, $16 \%$ lipids and $1 \%$ chromium oxide as inert digestibility marker. Fish meal and fish oil were used as protein and lipid sources in the reference diet, and gelatinized corn starch as carbohydrate source. Two other diets were formulated by mixing $70 \%$ of the reference diet and $30 \%$ of a test ingredient; two different sources of DDGS. DDGS ${ }_{1}$ was supplied by Biocarburantes Castilla y Leon, Spain and DDGS 2 was supplied by Pannonia Gold, Hungary. All dietary ingredients were finely ground, thoroughly mixed and steam pelleted using a laboratory pellet mill (California Pellet Mill, Crawfordsville, IN, USA) through $3 \mathrm{~mm}$ die. After drying in an oven for $24 \mathrm{~h}$ at $35^{\circ} \mathrm{C}$ the pellets were sieved and stored at $-20{ }^{\circ} \mathrm{C}$ until use. Proximate analysis of test ingredients is presented in table 1, and composition and proximate analysis of the experimental diets is presented in table 2.

\subsection{Digestibility trials}

The digestibility trials were performed at the Marine Zoological Station, University of Porto, Portugal, with European seabass (Dicentrarchus labrax) and meagre (Argyrosomus regius) juveniles provided by Instituto Português do Mar e da Atmosfera (IPMA) pilot aquaculture facility, at Algarve. The trials were conducted by trained scientists (following FELASA category C recommendations) according to the European Union Directive (2010/63/EU) on the protection of animals for scientific purposes.

The experimental system consisted of a thermo-regulated recirculation water system equipped with nine fiberglass tanks of $60 \mathrm{~L}$ water capacity, each one with a feces settling column connected to the outlet, designed according Cho et al. (1982). During the trial, water-flow was established at about $4.5 \mathrm{~L} / \mathrm{min}$ per tank, water temperature averaged $22{ }^{\circ} \mathrm{C}$, salinity averaged $38 \%$ and dissolved oxygen was kept above $90 \%$ of saturation.

For the seabass trial, six fish with an average weight of $206 \mathrm{~g}$ were established in each tank and allowed to acclimate to the experimental conditions for 15 days. During this period, fish were daily fed a commercial diet (Aquagold $3 \mathrm{~mm}$, Aquasoja, Soja de Portugal, S.A; 44\% crude protein, $14 \%$ crude fat, $8 \%$ ash, $2.5 \%$ crude fibre, $1.0 \%$ phosphorus). Thereafter, the experimental diets were randomly assigned to triplicate groups of fish and the animals were 
fed twice a day, at $9.30 \mathrm{~h}$ and $16.30 \mathrm{~h}$, to apparent satiation. Fish were adapted to the diets during 7 days and then feces were daily collected for 24 days. Feces accumulated in each settling column were daily collected before the morning meal, centrifuged at $3000 \times \mathrm{g}$, and stored at $-20^{\circ} \mathrm{C}$ until analysis. Thirty minutes after the afternoon meal, tanks, pipes, and settling columns were thoroughly cleaned to remove excess feed and feces. Feces collected during the sampling period were pooled for each tank.

For the meagre trial, nine fish with an average body weight of $78.8 \mathrm{~g}$ were established in each tank, and the experimental procedure was identical to that described above. 
Apparent digestibility coefficients (ADCs) of protein, amino acids, lipid, dry matter, and energy of the diets were determined by the following formula:

$$
A D C_{\text {diet }}=\left[1-\left(\frac{\text { dietary } \mathrm{Cr}_{2} \mathrm{O}_{3} \text { level } \times \text { feces nutrient or energy level }}{\left(\text { feces } \mathrm{Cr}_{2} \mathrm{O}_{3} \text { level } \times \text { dietary nutrient or energy level }\right)}\right)\right] \times 100
$$

The apparent digestibility coefficients of the test ingredients were calculated according to Bureau et al. (1999) as follows:

$$
\mathrm{ADC}_{\text {test ingredient }}=\mathrm{ADC}_{\text {test diet }}+\left[\left(\mathrm{ADC}_{\text {test diet }}-\mathrm{ADC}_{\text {ref.diet }}\right) \times\left(0.7 \times \mathrm{D}_{\text {ref. }} / 0.3 \times \mathrm{D}_{\text {ingr. }}\right)\right]
$$

where $D_{\text {ref. }}$ is the $\%$ nutrient (or $\mathrm{kJ} \mathrm{g}^{-1}$ ) of reference diet (dry matter basis) and $D_{\text {ingr }}$ is the \% nutrient (or kJ g${ }^{-1}$ ) of test ingredient (dry matter basis).

\subsection{Intestine sampling}

After each digestibility trial fish continued to be fed for more 5 days and then the intestine was sampled for measuring digestive enzymes activity in full fed fish, to avoid bias due to effects of fasting, following previous recommendations (Krogdahl and McKellep, 2005). To ensure that the intestine was full at sampling time, fish were continuously fed during the sampling collection. Two fish per tank were randomly sampled, euthanized with a sharp blow in the head, and immediately eviscerated in an ice-cooled tray. The digestive tract was excised, adherent adipose and connective tissues carefully removed, and the intestine divided in three portions: anterior, mid and distal intestine. For both species, the distal intestine was distinguished from de mid intestine by the increased diameter, darker mucosa, and annular rings. The anterior and mid portions of intestine were obtained by the division of the remaining intestine in two identical parts. The anterior intestine is the portion directly after the stomach and included the pyloric caeca. The intestine sections were immediately frozen in liquid nitrogen and then stored at $-80^{\circ} \mathrm{C}$ until measurement of enzymes activity. 


\subsection{Chemical analysis}

Chemical analysis of ingredients, diets and feces were conducted as follows: dry matter, by drying the samples at $105^{\circ} \mathrm{C}$ until constant weight; ash, by incineration in a muffle furnace at $450^{\circ} \mathrm{C}$ for 16 hours; protein $(\mathrm{N} \times 6.25)$ by the Kjeldahl method following acid digestion, using Kjeltec digestion and distillation units (Tecator Systems, Höganäs, Sweden; models 1015 and 1026, respectively); lipids in ingredients and diets by extraction with petroleum ether using a Soxtec system (Tecator Systems, Höganäs, Sweden; extraction unit model 1043 and service unit model 1046), and in feces by a gravimetric method (Folch et al., 1957) due to the limited amount of feces sample; gross energy, by direct combustion of samples in an adiabatic bomb calorimeter (PARR Instruments, Moline, IL, USA; PARR model 1261); chromic oxide by acid digestion according to Furukawa and Tsukahara (1966); crude, acid and neutral detergent fiber by the methods of Van Soest et al., (1991) using an ANKOM 200 Fiber Analyzer; total phosphorus by a colorimetric method, according to Fiske and Subbarow (1925). Amino acid analysis was done according to Peres and Oliva-Teles (2009). Briefly, samples were hydrolyzed for $23 \mathrm{~h}$ with $6 \mathrm{~N}$ hydrochloric acid at $110{ }^{\circ} \mathrm{C}$ under nitrogen atmosphere and derivatized with phenylisothiocyanate (PITC; Pierce) reagent before separation by high performance liquid chromatography (HPLC) in a Waters Reversed-Phase Amino Acid Analysis System (Waters auto sample model 717 plus; Waters binary pump model 1525; Waters dual absorbance detector model 2487), equipped with a PicoTag column, using the conditions described by Cohen et al., (1989). External standards (Pierce NC10180) were prepared along with the samples and norleucine was used as internal standard to detect any losses due to the sample processing. Chromatographic peaks were identified, integrated and quantified with the Waters Breeze software package by comparing to known amino acid standards.

\subsection{Digestive enzymes activity}

For enzymatic activity measurement, each section of intestine was homogenized in ice-cold buffer (100 mM Tris-HCl, 0.1 mM EDTA and 0.1\% Triton X-100 (v/v), pH 7.8), centrifuged (30 $000 \times \mathrm{g} ; 30 \mathrm{~min} ; 4^{\circ} \mathrm{C}$ ) and resultant supernatant collected and stored at $-80^{\circ} \mathrm{C}$, until analyses. 
All enzyme activities were determined using a PowerWavex microplate scanning spectrophotometer (Bio-Tek Instruments, USA).

Total protease activity was measured by the casein-hydrolysis method, at $\mathrm{pH} 8$ using $0.1 \mathrm{M}$ tris $\mathrm{HCl}$ as buffer, according to Walter (1984) and adapted by (Hidalgo et al., 1999). The pH 8 was chosen as it is within the optimum $\mathrm{pH}$ for physiological protease activity both in seabass (Alliot et al., 1974) and in meagre (Castro et al., 2013). The reaction mixture, containing casein $(1 \% \mathrm{w} / \mathrm{v} ; 0.125 \mathrm{ml})$, buffer $(0.125 \mathrm{ml})$ and homogenate supernatant $(0.05 \mathrm{ml})$, was incubated for 1 hour at $37^{\circ} \mathrm{C}$ and stopped by adding $0.3 \mathrm{ml}$ trichloroacetic acid $(8 \% \mathrm{w} / \mathrm{v})$ solution. After being kept for $1 \mathrm{~h}$ at $2^{\circ} \mathrm{C}$, samples were centrifuged ( $\left.1800 \times \mathrm{g} ; 10 \mathrm{~min}\right)$ and the absorbance read at $280 \mathrm{~nm}$ against blanks. Blanks were prepared by adding the supernatant from the homogenates after incubation. Tyrosine solution was used to establish a calibration curve. One unit of enzyme activity was defined as the amount of enzyme needed to catalyze the formation of $1.0 \mu \mathrm{mol}$ of tyrosine per min. $\alpha$-Amylase (EC 3.2.1.1) and lipase (EC 3.1.1.3) activities were measured with commercial kits (Spinreact ref. 41201 and ref. 1001274, respectively); for both enzyme activity was expressed as specific activity; one unit $(U)$ of activity was defined as $\mu \mathrm{mol}$ of product generated per minute. Soluble protein was determined according to Bradford (1976), with bovine serum albumin solution as standard.

\subsection{Statistical analysis}

All statistical analyses were performed using SPSS 21.0 software package for Windows. ADCs of diets and ingredients, and digestive enzymes activity were analyzed by two-way ANOVA; if diet/ingredient $\times$ species interaction was significant, then were compared diet/ingredient effect was evaluated separately for each species by a one-way ANOVA. For each species, the effect of dietary treatments on digestive enzyme activity, in each gastrointestinal section, was analyzed by one-way ANOVA. Significant differences between means were determined by the Tukey multiple range test. All analyses were performed using the probability level of 0.05 for rejection of the null hypothesis. To meet ANOVA requirements (homoscedasticity and normality), ADCs data were subjected to arcsin square root transformation, and enzymatic activity after natural log transformation. 


\section{Results}

The ADCs of the reference diet was very high in both species, with ADCs of protein being 8992\%, lipids $98-99 \%$, energy $92-94 \%$ and of most amino acids $88-100 \%$ (Table 3 ). The ADCs of dry matter, protein and energy were however higher in seabass than in meagre. Similarly, ADCs of lysine, histidine, leucine, phenylalanine, aspartic acid and glutamic acid were also higher for seabass than for meagre.

The ADCs of dry matter, lipids and energy were higher for the reference diet than for the DDGS diets, but the ADCs of protein was higher for $\mathrm{DDGS}_{1}$ diet than for the other diets. Irrespectively of the species, ADCs of amino acid was lower in DDGS diets than in the reference diet. For DDGS diets, ADCs of lysine was higher for $\mathrm{DDGS}_{2}$ diet while ADCs of glutamic acid, alanine, and proline were higher for DDGS 1 diet (Table 3).

The ADCs of DDGS products were not affected by species, except for lysine, arginine, histidine, isoleucine, tyrosine, and aspartic acid, which were higher for seabass than for meagre (Table 4). The ADCs of dry matter, protein, and energy were higher for $\mathrm{DDGS}_{1}$ than for $\mathrm{DDGS2}_{2}$, but the ADCs of lipids and most amino acid were similar in the two feedstuffs.

The specific activity of digestive enzymes in the anterior, mid and distal intestine sections of seabass and meagre are presented in Table 5 and Table 6, respectively. Overall, in both species digestive enzymes activity were higher in mid intestine than in anterior or distal intestine.

Total protease, lipase and amylase activities, calculated as the sum of activities in anterior, mid and distal intestine, and the ratios between digestive enzymes activities were speciesdependent (Table 7). Total protease activity was higher in meagre (728 mU mg protein ${ }^{-1}$ ) than in seabass (226 mU mg protein ${ }^{-1}$ ), while the opposite was true for lipase (10 and $15 \mathrm{mU}$ mg protein ${ }^{-1}$, respectively) and for amylase (62 and $69 \mathrm{mU} \mathrm{mg}$ protein ${ }^{-1}$, respectively)

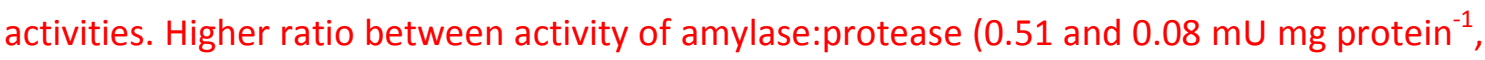
respectively), lipase:protease (0.07 and $0.01 \mathrm{mU} \mathrm{mg}$ protein $^{-1}$, respectively) and amylase:lipase (11 and $7 \mathrm{mU} \mathrm{mg}$ protein $^{-1}$ respectively) were found in seabass than in meagre. Irrespective of species, total protease activity of was not affected by diet but total 
lipase and amylase activities, and amylase:protease and lipase:protease ratios were higher in fish fed the DDGS 2 diet than the other diets. 


\section{Discussion}

Chemical composition of DDGS is variable and highly dependent on processing technology (Schaeffer et al., 2011; U. S. Grains, 2012). The nutritional value and nutrient content of corn DDGS may be greatly affected by quality of the grains used, fermentation efficiency, temperature and time of drying process, and quantity of solubles added to the grains (Lim et al., 2011; Liu 2012). Accordingly, although the two commercial corn DDGS products tested in this study had very similar nutrient composition, the ADCs of dry matter, protein and energy were significantly different, with $\mathrm{DDGS}_{1}$ being more digestible than $\mathrm{DDGS}_{2}$. This variability of nutrient content and bioavailability among DDGS products can be a challenge when determining its nutritional and economic value for use in aquafeeds formulation.

In this study, the ADCs of protein in both DDGS were similar (92\%; DDGS $)$ ) or higher (96\%; $D_{D G S_{1}}$ ) than that of fish meal (89-92\%), the only protein source in the reference diet. High digestibility of corn DDGS protein (88-92\%; Cheng et al., 2004) or of high protein distiller's dried grains (93\%; Prachom et al., 2013) was also observed in rainbow trout. On the other hand, digestibility of DDGS protein was only $65 \%$ in sunshine bass (Thompson et al., 2008). In this study, unfortunately, information is not provided on the grain used for DDGS production and therefore adequate comparison of data with the other studies is not possible.

Nevertheless, digestibility may be affected by several factors including species, fish size and water temperature (NRC, 2011), in the present study the digestibility of DDGS products was similar in both species, except for some amino acids, namely lysine, arginine, histidine, isoleucine, tyrosine, and aspartic acid, which were higher in seabass than in meagre. This may be related to the similar carnivorous feeding habits of both species, as both species were maintained at the same water temperature, closed to the optimum temperature for these species (22 ㄷ; FishBase). However, it cannot be excluded that differences in body weight of both species (206 g vs $79 \mathrm{~g}$ ) may have also affect the ADCs. Further studies should be performed in order to confirm if it is possible to extrapolate feedstuff digestibility data between the two species.

The ADCs of lysine, arginine, histidine and isoleucine were higher in seabass than in meagre, showing the importance of taking into account not only the protein digestibility but also the digestibility of each amino acid when formulating diets. During DDGS production, corn is 
exposed to different temperatures ( 32 to 100 을 that may reduce protein quality and amino acid bioavailability. In this study, even though protein digestibility of DDGS diets was not lower than that of the control diet, the ADCs of DGGS amino acids tended to be lower than in the control diet (fish meal based diet). This is further reflected in the lower digestibility of amino acids in DDGS products comparatively to fish meal. There were, however, no differences in amino acid digestibility between the two DDGS feedstuffs, except for glutamic acid and proline. These data reinforce the need to evaluate not only the digestibility of essential amino acids but also of non-essential amino acids. Indeed, while at present little importance has been given to the non-essential amino acid fraction in diet formulation, growing evidence shows the importance of dietary essential/non-essential amino acids ratio (Peres and Oliva-Teles, 2006) and the source of non-essential nitrogen (Gaye-Siessegger et al., 2007; Abboudi et al., 2009; Figueiredo-Silva et al., 2010). Indeed, it was recently demonstrated in terrestrial animal that adequate provision of both essential and nonessential amino acids is critical for maximum efficiency of animal production, being expectable that more attention to non-essential amino acids will be given during feed formulation (Wu, 2014).

Contrary to corn meal, corn DDGS is a good source of lipids. DDGS products used in this study had a lipid content of 11.8-12.8\%, which was higher than in fish meal (9.2\%). However, the ADCs of lipids was lower in DDGS products (82-89\%) than in fish oil (98.5\%; value of the reference diet in which fish oil is the major lipid). Digestibility of lipids in DDGS was within the range of values previously determined for rainbow trout (79-89\%; Cheng et al., 2004) and it was higher than that determined in sunshine bass (69\%; Thompson et al., 2008). The lower ADCs of lipids in DDGS products comparatively to fish oil may be related to differences in fatty acid composition. Further, contrary to the original grain, DDGS usually contain high levels of free fatty acids: $6-8 \%$ in DDGS vs. 1-2\% in corn (Liu, 2012). Differences in lipid digestibility may be also related to functional modifications at the intestine level induced by lipids, as it is known that inclusion of vegetable oils in carnivorous fish diets can negatively affect digestive and absorptive processes (Santigosa et al., 2011). Modifications of enterocyte membranes were also described in fish fed vegetable oils (Sitja-Bobadilla et al., 2005) and this can compromise the intestinal function, thus reducing lipid digestibility (Geurden et al., 2009). 
Low ADCs of energy (58-68\%) and of dry matter (57-66\%) of DDGS products is most certainly related to the high fiber content, as it is known that fish, especially carnivorous species, poorly digest complex carbohydrates (Enes et al., 2011). Indeed, non-digestible carbohydrates, if present in high quantity, may also impair digestibility of other nutrients by reducing gut-retention time of feed and time available for nutrients absorption (Stone, 2003; Fontoulaki et al., 2005; Enes et al., 2011). This was not the case of protein digestibility, but potential effect on lipid digestibility of DDGS products cannot be excluded. In rainbow trout, the ADCs of energy (51-67\%) and dry matter (47-59\%) of DDGS were also low but within the range observed in the present study (Cheng et al., 2004). In contrast, in rainbow trout fed practical diets in which a mixture of plant protein ingredients (sunflower, rapeseed meal and field peas) were replaced by DDGS no differences in ADCs of energy were observed relatively to the control diet (Overland et al., 2013). In sunshine bass the ADCs of dry matter of DDGS was extremely low (10\%) and this may contribute to explain the low ADCs of protein and lipids (65 and 69\%, respectively) observed in that study (Thompson et al., 2008).

Overall, digestive amylase and lipase activities were lower in fish fed diet DDGS ${ }_{1}$ than diet $\mathrm{DDGS}_{2}$, while protease activity was not affected by DDGS source. The higher amylase and lipase activities in fish fed diet $\mathrm{DDGS}_{2}$ may be related to the higher dietary starch and lipid levels in this diet comparatively to diet $\mathrm{DDGS}_{1}$, as it is known that digestive enzymatic activity is modulated by diet composition (Bakke et al., 2011).

In this study, highest enzyme activity was observed in the mid intestine, both in seabass and in meagre. In seabass it was previously observed higher protease activity in the pyloric caeca (included in the anterior intestine fraction as in our study) than in the rest of intestine (Alliot et al., 1974) while in meagre proteolytic activity was identical in pyloric caeca and intestine (Castro et al., 2013). In fish, most part of nutrient digestion generally takes place in the anterior intestine and, to a lesser extent, in the mid intestine; the distal intestine usually have lower digestive enzyme activity (Tibaldi et al., 2006; Correa et al., 2007; Gai et al., 2012). However, different digestive enzymes profile, along the digestive tract, may occur depending on species (Pérez-Jiménez et al., 2009). A higher digestive enzyme activity in the mid intestine may be somehow artificial, due to possible drag of secreted mucous to that part of the digestive tract (Pérez-Jiménez et al., 2009; Gai et al., 2012). The high level of fiber in DDGS diets may also induce dragging of chime along the digestive tract and consequently 
a displacement of maximum enzyme activity from the anterior to the mid region of the intestine. This however does not seem to have been the case in this study, as the highest level of digestive enzymes activities were observed in the mid intestine, independently of diet composition.

Total protease activity was much higher in meagre than in seabass, reflecting the higher carnivorous feeding habits of meagre (trophic level 4.3 in meagre and 3.8 in seabass; FishBase). Though protease activity may be influenced by diet composition (Santigosa et al., 2008; Pérez-Jiménez et al., 2009), this was not the case in this study as dietary protein content of reference and DDGS diets differed considerably. Protease activity was previously determined in meagre fed dietary brewer's spent yeast supplementation and, as in the present study, no differences relatively to the fish meal based control diet were also noticed (Castro et al., 2013). Other studies with carnivorous fish also observed unresponsive protease activity to different protein levels (Lundsted et al., 2004). However, induction of proteolytic activity in response to dietary protein level was observed in seabass larvae (Peres et al., 1996), carp and rainbow trout juveniles (Kawai and Ikeda, 1972; 1973).

Amylase activity, amylase:protease, and amylase:lipase ratios were higher in seabass than in meagre, which is in accordance to the higher carnivorous feeding habit of meagre. Amylase activity is usually affected by diet composition, with higher activities being observed in fish fed higher carbohydrate levels (Peres et al., 1996; Keshavanath et al., 2002; Fontoulaki et al., 2005; Correa et al., 2007; Pérez-Jiménez et al., 2009). Accordingly, higher amylase activity was observed in fish fed diet DDGS 2 than diet DDGS ${ }_{1}$. However, although starch content of the control diet was identical to that of diet $\mathrm{DDGS}_{2}$, amylase activity was higher in fish fed the $\mathrm{DDGS}_{2}$ diet. Differences in feed intake (not measured) between fish fed the different diets may contribute to explain the observed differences, but it will require further investigation.

Lipase activity may also differ between species, even between related species (Bakke et al., 2011). In this study, lipase activity and lipase:protease ratio were higher in seabass than in meagre, which is in accordance to the higher tolerance to dietary lipid levels in seabass (more than $24 \%$, Peres and Oliva-Teles, 1999) comparatively to meagre (less than $17 \%$, Chatzifotis et al., 2012). 
In conclusion, apparent digestibility of tested DDGS products was similar in seabass and meagre, and it was higher for $D_{D G S}$ than for $D D G S_{2}$. ADCs of protein and lipids of DDGS products were high, while ADCs of dry matter and energy were moderate, reflecting the high indigestible fiber content of DDGS products. Digestive enzymes activity was species specific, with protease activity being higher in meagre while amylase activity was higher in seabass; lipase activity was low and similar in both species. Though digestive enzymes activity was species specific and affected by diet composition, it had no overall effect in the ADCs of DDGS. Overall, corn DDGS seems to have high potential for inclusion in diets for seabass and meagre.

\section{Acknowledgements}

This work was partially funded by the Project AQUAIMPROV (ref.NORTE-07-0124-FEDER000038), co-financed by North Portugal Regional Operational Program (ON.2-O Novo Norte), under the National Strategic Reference Framework (NSRF), through the European Regional Development Fund (ERDF); by the Operational Competitiveness Program (COMPETE), through European Regional Development Fund (ERDF) and national funds through by Foundation for Science and Technology (FCT), under the project PestC/MAR/LA0015/ 2013. Meagre juvenile production was partially supported by "Projectopiloto de cultivo de corvina em vários sistemas de produção"- "AQUACOR". PROMAR 31-0305FEP-003. We would like to express our thanks to P. Correia for the assistance during the growth trial. Coutinho, F. was supported by a FCT grant (SFRH/BD/86799/2012).

\section{References}

Abboudi, T., Mambrini, M., Larondelle, Y., Rollin, X., 2009. The effect of dispensable amino acids on nitrogen and amino acid losses in Atlantic salmon (Salmo salar) fry fed a protein-free diet. Aquaculture. 289, 327-333.

Abo-State, H.A., Tahoun, A.M., Hammouda, Y.A., 2009. Effect of replacement of soybean meal by DDGS combined with commercial phytase on Nile tilapia (Oreochromis niloticus) fingerlings growth performance and feed utilization. Amerian-Eurasian J. Agric. \& Environ. Sci. 5, 473-479.

Alliot, E., Febvre, A., Métailler, R., 1974. Les protéases digestives chez un téléostéen carnivore Dicentrarchus labrax. Ann. Biol. Anim. Bioch. Biophys. 14, 229-237.

Bakke, A.M., Krogdahl, Å., 2005. Letter to the editor of Aquaculture. Aquaculture. 250, 541. 
Bakke, A.M., Glover, C., Krogdahl, Å., 2011. Feeding, digestion and absorption of nutrients. In: Fish Physiology, Martin-Grosell, A.P.F., Colin, J.B. (Eds.), Academic Press, pp. 57-110.

Bradford,M., 1976. A rapid and sensitive method for the quantitation of microgram quantities of protein using the principle of protein dye-binding. Anal. Biochem. 72, 248-254.

Brown, M.L., Schaeffer, T.W., Rosentrater, K.A., Barnes, M.E., Muthukumarappan, K., 2012. Feeding DDGS to Finfish. In. Distillers Grains: Production, Properties, and Utilization; Liu, K., Rosentrater, A. (Eds), CRC Press, Taylor \& Francis Group Boca Raton, FI, USA, pp. 341-390.

Bureau, D.P., Harris, A.M., Cho, C.Y., 1999. Apparent digestibility of rendered animal protein ingredients for rainbow trout (Oncorhynchus mykiss). Aquaculture 180, 345-358.

Castro, C., Perez-Jimenez, A., Coutinho, F., Pousao-Ferreira, P., Brandao, T.M., Oliva-Teles, A., Peres, H., 2013. Digestive enzymes of meagre (Argyrosomus regius) and white seabream (Diplodus sargus). Effects of dietary brewer's spent yeast supplementation. Aquaculture. 416, 322-327.

Chatzifotis, S., Panagiotidou, M., Divanach, P., 2012. Effect of protein and lipid dietary levels on the growth of juvenile meagre (Argyrosomus regius). Aquaculture International. 20, 91-98.

Cheng, Z.J., Hardy, R.W., 2004. Nutritional value of diets containing distiller's dried grain with solubles for rainbow trout, Oncorhynchus mykiss. J. Appl.Aquac. 15, 101-113.

Cho, C.Y., Slinger, S.J., Bayley, H.S., 1982. Bioenergetics of salmonid fishes: energy intake, expenditure and productivity. Comp. Biochem. Physiol. 73B, 25-41.

Cohen, S.A., Meys, M.,Tarvin, T., 1989. The pico-tag method. A manual of advance techniques for amino acid analysis. Milford, MA.

Correa, C.F., de Aguiar, L.H., Lundstedt, L.M., Moraes, G., 2007. Responses of digestive enzymes of tambaqui (Colossoma macropomum) to dietary cornstarch changes and metabolic inferences. Comp. Biochem. Physiol. A-Mol. Integr. Physiol. 147, 857-862.

Coyle, S. D., Mengel, G. J., Tidwell, J. H., Webster, C. D., 2004. Evaluation of growth, feed utilization, and economics of hybrid tilapia, Oreochromis niloticus $\mathrm{x}$ Oreochromis aureus, fed diets containing different protein sources in combination with distillers dried grains with solubles. Aquaculture Research. 35, 365-370.

Enes, P., Panserat, S., Kaushik, S., Oliva-Teles, A., 2011. Dietary carbohydrate utilization by European sea bass (Dicentrarchus labrax L.) and gilthead sea bream (Sparus aurata L.) juveniles. Rev. Fish. Sci. 19, 201-215.

Figueiredo-Silva, A.C., Corraze, G., Kaushik, S., Peleteiro, J.B., Valente, L.M.P., 2010. Modulation of blackspot seabream (Pagellus bogaraveo) intermediary metabolic pathways by dispensable amino acids. Amino Acids. 39, 1401-1416.

Fiske, C.A., Subbarow, I., 1925. The colorimetric determination of phosphorus. J. Bio. Chem. $66,375-400$.

Folch, J., Lees, M., Sloane-Stanley, G.H.S., 1957. A simple method for the isolation and purification of total lipids from animal tissue. J. Biol. Chem. 226, 497-509. 
Fontoulaki, E., Alexis, M.N., Nengas, I., Venou, B., 2005. Effect of diet composition on nutrient digestibility and digestive enzyme levels of gilthead sea bream (Sparus aurata L.). Aquac Res. 36, 1243-1251.

Furukawa, A., Tsukahara, H., 1966. On the acid digestion method for the determination of chromic oxide as an index substance in the study of digestibility of fish feed. Nippon Suisan Gakk 32, 502-506.

Gai, F., Gasco, L., Dapra, F., Palmegiano, G.B., Sicuro, B., 2012. Enzymatic and Histological Evaluations of Gut and Liver in Rainbow Trout, Oncorhynchus mykiss, Fed with Rice Protein Concentrate-based Diets. J. World Aquacult. Soc. 43, 218-229.

Gatlin, D.M., Barrows, F.T., Brown, P., Dabrowski, K., Gaylord, T.G., Hardy, R.W., Herman, E., Hu, G.S., Krogdahl, A., Nelson, R., Overturf, K., Rust, M., Sealey, W., Skonberg, D., Souza, E.J., Stone, D., Wilson, R., Wurtele, E., 2007. Expanding the utilization of sustainable plant products in aquafeeds: a review. Aquac. Res. 38, 551-579.

Gaye-Siessegger, J., Focken, U., Abel, H., Becker, K., 2007. Influence of dietary non-essential amino acid profile on growth performance and amino acid metabolism of Nile tilapia, Oreochromis niloticus (L.). Comparative Biochemistry and Physiology a-Molecular \& Integrative Physiology. 146, 71-77.

Geurden, I., Jutfelt, F., Olsen, R.E., Sundell, K.S., 2009. A vegetable oil feeding history affects digestibility and intestinal fatty acid uptake in juvenile rainbow trout Oncorhynchus mykiss. Comp. Biochem. Physiol. A-Mol. Integr. Physiol. 152, 552-559.

Hertrampf, J.W., Piedad-Pascual, F., 2000. Handbook on ingredients for aquaculture feeds. Kluwee Academic Publishers, The Netherlands, 138pp.

Hidalgo, M.C., Urea, E., Sanz, A., 1999. Comparative study of digestive enzymes in fish with different nutritional habits. Proteolytic and amylase activities. Aquaculture 170, 267283.

Karapanagiotidis, I.T., 2014. The Re-Authorization of Non-Ruminant Processed Animal Proteins in European Aqua feeds. Aqua feeds. Fish Aquac. J. 5, 4.

Kawai, S., Ikeda, S., 1972. Studies on digestive enzymes of fishes. 2. Effect of dietary change on activities of digestive enzymes in carp intestine. Nippon Suisan Gakk . 38, 265-270.

Kawai, S.I., Ikeda, S., 1973. Studies on digestive enzymes of fishes. 3. Development of digestive enzymes of rainbow-trout after hatching and effect of dietary change on activities of digestive enzymes in juvenile stage. Nippon Suisan Gakk 39, 819-823.

Keshavanath, P., Manjappa, K., Gangadhara, B., 2002. Evaluation of carbohydrate rich diets through common carp culture in manured tanks. Aquaculture Nutrition. 8, 169-174.

Krogdahl, Å., Bakke, A.M., 2005. Fasting and refeeding cause rapid changes in intestinal tissue mass and digestive enzyme capacities of Atlantic salmon (Salmo salar L.). Comparative Biochemistry and Physiology. 141(A), 450 - 460.

Li, M.H., Oberle, D.F., Lucas, P.M., 2011. Evaluation of corn distillers dried grains with solubles and brewers yeast in diets for channel catfish Ictalurus punctatus (Rafinesque). Aquac. Res. 42, 1424-1430.

Lim, C., Li, E., Klesius, P.H., 2011. Distiller's dried grains with solubles as an alternative protein source in diets of tilapia. Reviews in Aquaculture. 3, 172-178. 
Liu, K., 2012. Chemical Composition of DDGS, Distillers Grains. In Production, Properties, and Utilization. Liu, K., Rosentrater, A. (Eds), CRC Press, Taylor \& Francis Group, Boca Raton, $\mathrm{Fl}, \mathrm{USA}$, pp. pp 143-178.

Lundstedt, L. M., Melo, J. F. B., Moraes, G., 2004. Digestive enzymes and metabolic profile of Pseudoplatystoma corruscans (Teleostei : Siluriformes) in response to diet composition. Comp. Biochem. Physiol., Part B: Biochem. Mol. Biol. 137, 331-339.

National Research Council (NRC) (2011) Nutrient Requirements of Fish and Shrimp. National. Acad. Press, Washington, DC.

Oliva-Teles, A., 2012. Nutrition and health of aquaculture fish. J. Fish Dis. 35, 83-108.

Overland, M., Krogdahl, A., Shurson, G., Skrede, A., Denstadli, V., 2013. Evaluation of distiller's dried grains with solubles (DDGS) and high protein distiller's dried grains (HPDDG) in diets for rainbow trout (Oncorhynchus mykiss). Aquaculture 416, 201-208.

Peres, A., Cahu, C.L., Infante, J.L.Z., LeGall, M.M., Quazuguel, P., 1996. Amylase and trypsin responses to intake of dietary carbohydrate and protein depend on the developmental stage in sea bass (Dicentrarchus labrax) larvae. Fish Physiol. Biochem. 15, 237-242.

Peres, H., Oliva-Teles, A., 1999. Effect of dietary lipid level on growth performance and feed utilization by European sea bass juveniles (Dicentrarchus labrax). Aquaculture. 179, 325-334.

Peres, H., Oliva-Teles, A., 2006. Effect of the dietary essential to non-essential amino acid ratio on growth, feed utilization and nitrogen metabolism of European sea bass (Dicentrarchus labrax). Aquaculture. 256, 395-402.

Peres, H., Oliva-Teles, A., 2009. The optimum dietary essential amino acid profile for gilthead seabream (Sparus aurata) juveniles. Aquaculture 296, 81-86.

Pérez-Jiménez, A., Cardenete, G., Morales, A.E., Garcia-Alcazar, A., Abellan, E., Hidalgo, M.C., 2009. Digestive enzymatic profile of Dentex dentex and response to different dietary formulations. Comp. Biochem. Physiol. A-Mol. Integr. Physiol. 154, 157-164.

Prachom, N., Haga, Y., Satoh, S., 2013. Impact of dietary high protein distillers dried grains on amino acid utilization, growth response, nutritional health status and waste output in juvenile rainbow trout (Oncorhynchus mykiss). Aquac. Nutr. 19, 62-71.

Renewable Fuels Association, 2013. 2013 Ethanol Industry Outlook. Renewable Fuels Association, Washington, DC, USA

Robinson, E.H., Li, M.H., 2008. Replacement of soybean meal in channel catfish, Ictalurus punctatus, diets with cottonseed meal and distiller's dried grains with solubles. J. World Aquacult. Soc. 39, 521-527.

Rollin, X., Mambrini, M., Abboudi, T., Larondelle, Y., Kaushik, S.J., 2003. The optimum dietary indispensable amino acid pattern for growing Atlantic salmon (Salmo salar L.) fry. Brit J Nutr. 90, 865-876.

Salama, F.A., Ali, M.N., Mahmoud, S.H., Tonsy, H.D., Hassouna, M.M.E., 2011. Effects of radish root extract on improving the utilization of corn dried distillers grains with solubles in Nile tilapia (Oreochromis niloticus) fry diets. American-Eurasian J. Agric. \& Environ. Sci. 10, 938-946. 
Santigosa, E., Garcia-Meilan, I., Valentin, J.M., Navarro, I., Perez-Sanchez, J., Gallardo, M.A., 2011. Plant oils' inclusion in high fish meal-substituted diets: effect on digestion and nutrient absorption in gilthead sea bream (Sparus aurata L.). Aquac Res. 42, 962-974.

Santigosa, E., Sanchez, J., Medale, F., Kaushik, S., Perez-Sanchez, J., Gallardo, M.A., 2008. Modifications of digestive enzymes in trout (Oncorhynchus mykiss) and sea bream (Sparus aurata) in response to dietary fish meal replacement by plant protein sources. Aquaculture 282, 68-74.

Schaeffer, T.W., Brown, M.L., Rosentrater, K.A., 2011. Effects of dietary distillers dried grains with solubles and soybean meal on extruded pellet characteristics and growth responses of juvenile yellow perch. N. Am. J. Aqualcult. 73, 270-278.

Shelby, R.A., Lim, C., Yildrim-Aksoy, M., Klesius, P.H., 2008. Effect of distillers dried grains with solubles-incorporated diets on growth, immune function and disease resistance in Nile tilapia (Oreochromis niloticus L.). Aquac. Res. 39, 1351-1353.

Sitja-Bobadilla, A., Pena-Llopis, S., Gomez-Requeni, P., Medale, F., Kaushik, S., Perez-Sanchez, J., 2005. Effect of fish meal replacement by plant protein sources on non-specific defense mechanisms and oxidative stress in gilthead sea bream (Sparus aurata). Aquaculture. 249, 387-400.

Stein, H. 2006. DDGS: Energy and nutrient content and digestibility. Midwest Swine Nutrition Conference, pp. 58-65.

Stone, D.A.J., 2003. Dietary carbohydrate utilization by fish. Rev. Fish. Sci. 11, 337-369.

Stone, D.A.J., Hardy, R.W., Barrows, F.T., Cheng, Z.J., 2005. Effects of extrusion on nutritional value of diets containing corn gluten meal and corn distiller's dried grain for rainbow trout, Oncorhynchus mykiss. J. Appl. Aquaculture 17, 1-20.

Thompson, K.R., Rawles, S.D., Metts, L.S., Smith, R., Wimsatt, A., Gannam, A.L., Twibell, R.G., Johnson, R.B., Brady, Y.J., Webster, C.D., 2008. Digestibility of dry matter, protein, lipid, and organic matter of two fish meals, two poultry by-product meals, soybean meal, and distiller's dried grains with solubles in practical diets for sunshine bass, Morone chrysops x M-Saxatilis. J. World Aquacult. Soc. 39, 352-363.

Tibaldi, E., Hakim, Y., Uni, Z., Tulli, F., de Francesco, M., Luzzana, U., Harpaz, S., 2006. Effects of the partial substitution of dietary fish meal by differently processed soybean meals on growth performance, nutrient digestibility and activity of intestinal brush border enzymes in the European sea bass (Dicentrarchus labrax). Aquaculture 261, 182-193.

Tidwell, J.H., Webster, C.D., Yancey, H., 1990. Evaluation of destillers grains with solubles in prepared channel catfish diets. Trans. Ky. Acad. Sci. 51, 135-138.

Trushenski, J., Gause, B., 2013. Comparative value of fish meal alternatives as protein sources in feeds for hybrid striped bass. N. Am. J. Aqualcult. 75, 329-341.

U.S.Grains Council, 2012. A guide to distiller's dried grains with solubles (DDGS), $3^{\text {rd }}$ Edition ed.

Van Soest, P.J., Robertson, J.B., Lewis, B.A., 1991 Methods for dietary fiber, neutral detergent fiber, and nonstarch polysaccharides in relation to animal nutrition. J. Dairy Sci. 174, 3583-3597. 
Walter, H.E., 1984. Proteinases: methods with hemoglobin, casein and azocoll as substrates. In: Bergmeyer, H.J. (Ed.), Methods of Enzymatic Analysis, vol. V. Verlag Chemie, Weinham, pp. 270-277.

Webster, C.D., Tidwell, J.H., 1992. Use of distillers by-products in aquaculture diets. World Aquacult. Soc. 23, 55-57.

Webster, C.D., Tidwell, J.H., Goodgame, L.S., Yancey, D.H., Mackey, L., 1992h. Use of soybean meal and distillers grains with solubles as partial or total replacement of fish meal in diets for channel catfish, Ictalurus punctatus. Aquaculture 106, 301-309.

Webster, C.D., Tidwell, J.H., Yancey, D.H., 1991. Evaluation of distillers' grains with solubles as a protein source in diets for channel catfish. Aquaculture. 96, 179-190.

Wu, G., 2014. Dietary requirements of synthesizable amino acids by animals: a paradigm shift in protein nutrition. Journal of Animal Science and Biotechnology. 5, 34.

Wu, Y.V., Rosati, R., Sessa, D.J., Brown, P., 1994. Utilization of Protein Rich Ethanol CoProducts from Corn in Tilapia Feed. Journal of the American Oil Chemists Society. 71, 1041-1043.

Wu, Y.V., Rosati, R.R., Brown, P.B., 1996. Effect of diets containing various levels of protein and ethanol coproducts from corn on growth of tilapia fry. J. Agric. Food Chem. 44, 1491-1493.

Wu, Y.V., Rosati, R.R., Brown, P.B., 1997. Use of corn-derived ethanol coproducts and synthetic lysine and tryptophan for growth of tilapia (Oreochromis niloticus) fry. J. Agric. Food Chem. 45, 2174-2177. 
Table 1

Composition (\% dry matter) of fish meal and DDGS.

\begin{tabular}{|c|c|c|c|}
\hline Ingredient & Fish meal $^{1}$ & $\mathrm{DDGS}_{1}$ & $\mathrm{DDGS}_{2}$ \\
\hline Dry matter (\%) & 89.0 & 89.2 & 88.7 \\
\hline Protein & 70.7 & 30.4 & 29.4 \\
\hline Lipids & 9.2 & 11.8 & 12.8 \\
\hline Ash & 19.2 & 4.7 & 4.9 \\
\hline Crude fiber & - & 7.2 & 7.8 \\
\hline Acid detergent fiber & - & 14.6 & 13.8 \\
\hline Neutral detergent fiber & - & 42.4 & 39.3 \\
\hline Starch & - & 0.5 & 2.9 \\
\hline Nitrogen free extract & 0.9 & 45.9 & 45.1 \\
\hline Phosphorus & 2.5 & 0.5 & 0.8 \\
\hline Energy $\left(\mathrm{kJ} \mathrm{g}^{-1}\right)$ & 17.9 & 20.0 & 19.6 \\
\hline \multicolumn{4}{|l|}{ Essential amino acids } \\
\hline Lysine & 5.69 & 1.01 & 1.24 \\
\hline Arginine & 4.90 & 1.74 & 1.69 \\
\hline Histidine & 2.31 & 0.89 & 0.83 \\
\hline Isoleucine & 3.05 & 1.13 & 1.11 \\
\hline Leucine & 5.65 & 3.66 & 3.51 \\
\hline Valine & 3.77 & 1.65 & 1.57 \\
\hline Methionine & 1.97 & 0.72 & 0.67 \\
\hline Phenylalanine & 3.02 & 1.33 & 1.48 \\
\hline Threonine & 3.38 & 1.28 & 1.27 \\
\hline \multicolumn{4}{|c|}{ Non-essential amino acids } \\
\hline Tyrosine & 2.52 & 1.57 & 1.60 \\
\hline Aspartic Acid & 6.40 & 2.11 & 2.01 \\
\hline Glutamic Acid & 9.82 & 4.89 & 4.66 \\
\hline Serine & 3.12 & 1.70 & 1.61 \\
\hline Glycine & 4.88 & 1.24 & 1.17 \\
\hline Alanine & 5.41 & 2.33 & 2.20 \\
\hline Proline & 3.32 & 2.55 & 2.46 \\
\hline
\end{tabular}

${ }^{1}$ Steam Dried LT, Pesquera Diamante, Peru

$\mathrm{DDGS}_{1}$ : Biocarburantes de Castilla y Leon, Spain

DDGS $_{2}$ : Pannonia Gold, Hungry

Nitrogen Free Extract $=100-$ protein $(\% D M)-$ lipids $(\% D M)-$ ash $(\% D M)-$ fiber $(\% D M)$ 
2 Diet formulation and proximate composition (\% dry matter) of the experimental diets.

\begin{tabular}{|c|c|c|c|}
\hline Diet & Reference & $\mathrm{DDGS}_{1}$ & $\mathrm{DDGS}_{2}$ \\
\hline \multicolumn{4}{|l|}{ Ingredients } \\
\hline Fish meal & 63.2 & 44.2 & 44.2 \\
\hline Gelatinized corn starch ${ }^{1}$ & 22.1 & 15.4 & 15.4 \\
\hline Cod liver oil & 10.2 & 7.2 & 7.2 \\
\hline Vitamin premix ${ }^{2}$ & 1.0 & 0.7 & 0.7 \\
\hline Choline chloride (50\%) & 0.5 & 0.4 & 0.4 \\
\hline Mineral premix ${ }^{3}$ & 1.0 & 0.7 & 0.7 \\
\hline Binder ${ }^{4}$ & 1.0 & 0.7 & 0.7 \\
\hline Chromic oxide & 1.0 & 0.7 & 0.7 \\
\hline $\mathrm{DDGS}_{1}$ & - & 30.0 & - \\
\hline $\mathrm{DDGS}_{2}$ & - & - & 30.0 \\
\hline \multicolumn{4}{|l|}{ Proximate composition } \\
\hline Dry matter & 95.5 & 93.8 & 94.6 \\
\hline Protein & 45.6 & 41.2 & 41.3 \\
\hline Lipids & 15.9 & 13.6 & 15.4 \\
\hline Ash & 14.8 & 11.5 & 11.6 \\
\hline Crude fiber & - & 2.0 & 2.1 \\
\hline Starch & 13.6 & 9.0 & 12.7 \\
\hline Chromium oxide & 0.8 & 0.5 & 0.6 \\
\hline Phosphorus & 1.8 & 1.6 & 1.5 \\
\hline Energy $\left(\mathrm{kJ} \mathrm{g}^{-1}\right)$ & 20.0 & 20.7 & 20.8 \\
\hline \multicolumn{4}{|l|}{ Essential amino acids } \\
\hline Lysine & 3.61 & 2.65 & 2.64 \\
\hline Arginine & 3.19 & 2.68 & 2.69 \\
\hline Histidine & 1.89 & 1.33 & 1.21 \\
\hline Isoleucine & 1.74 & 1.71 & 1.71 \\
\hline Leucine & 3.64 & 3.75 & 3.69 \\
\hline Valine & 2.19 & 2.20 & 2.20 \\
\hline Methionine & 1.47 & 1.01 & 1.01 \\
\hline Phenylalanine & 1.89 & 1.79 & 1.79 \\
\hline Threonine & 2.21 & 1.83 & 1.83 \\
\hline \multicolumn{4}{|l|}{ Non-essential amino acids } \\
\hline Tyrosine & 1.63 & 1.72 & 1.73 \\
\hline Aspartic Acid & 4.44 & 3.08 & 2.89 \\
\hline Glutamic Acid & 6.41 & 6.06 & 6.03 \\
\hline Serine & 2.18 & 2.32 & 2.30 \\
\hline Glycine & 3.25 & 1.73 & 1.76 \\
\hline Alanine & 3.37 & 3.06 & 3.11 \\
\hline Proline & 2.25 & 3.60 & 3.63 \\
\hline
\end{tabular}

$3{ }^{1}$ Cerestar, France.

$4 \quad{ }^{2}$ Vitamins ( $\mathrm{mg} \mathrm{kg}^{-1}$ diet): retinol, 18,000 (IU kg-1 diet); calciferol, 2000 (IU kg-1 diet); alpha tocopherol, 35; 5 menadion sodium bis., 10; thiamin, 15; riboflavin, 25; Ca pantothenate, 50; nicotinic acid, 200; pyridoxine, 5;

6 folic acid, 10; cyanocobalamin, 0.02; biotin, 1.5; ascorbyl monophosphate, 50; inositol, 400.

$7{ }^{3}$ Minerals (mg kg ${ }^{-1}$ diet): cobalt sulphate, 1.91; copper sulphate, 19.6; iron sulphate, 200; sodium fluoride, 8 2.21; potassium iodide, 0.78 ; magnesium oxide, 830; manganese oxide, 26; sodium selenite, 0.66; zinc oxide, 937.5 ; dibasic calcium phsophate, 5.9 ( $\mathrm{g} \mathrm{kg}^{-1} \mathrm{diet}$ ); potassium chloride, 1.15 ( $\mathrm{g} \mathrm{kg}^{-1}$ diet); sodium chloride, 0.4 $10 \quad$ ( $\mathrm{g} \mathrm{kg}^{-1}$ diet).

$11{ }^{4}$ Binder (Aquacube. Agil, England). 


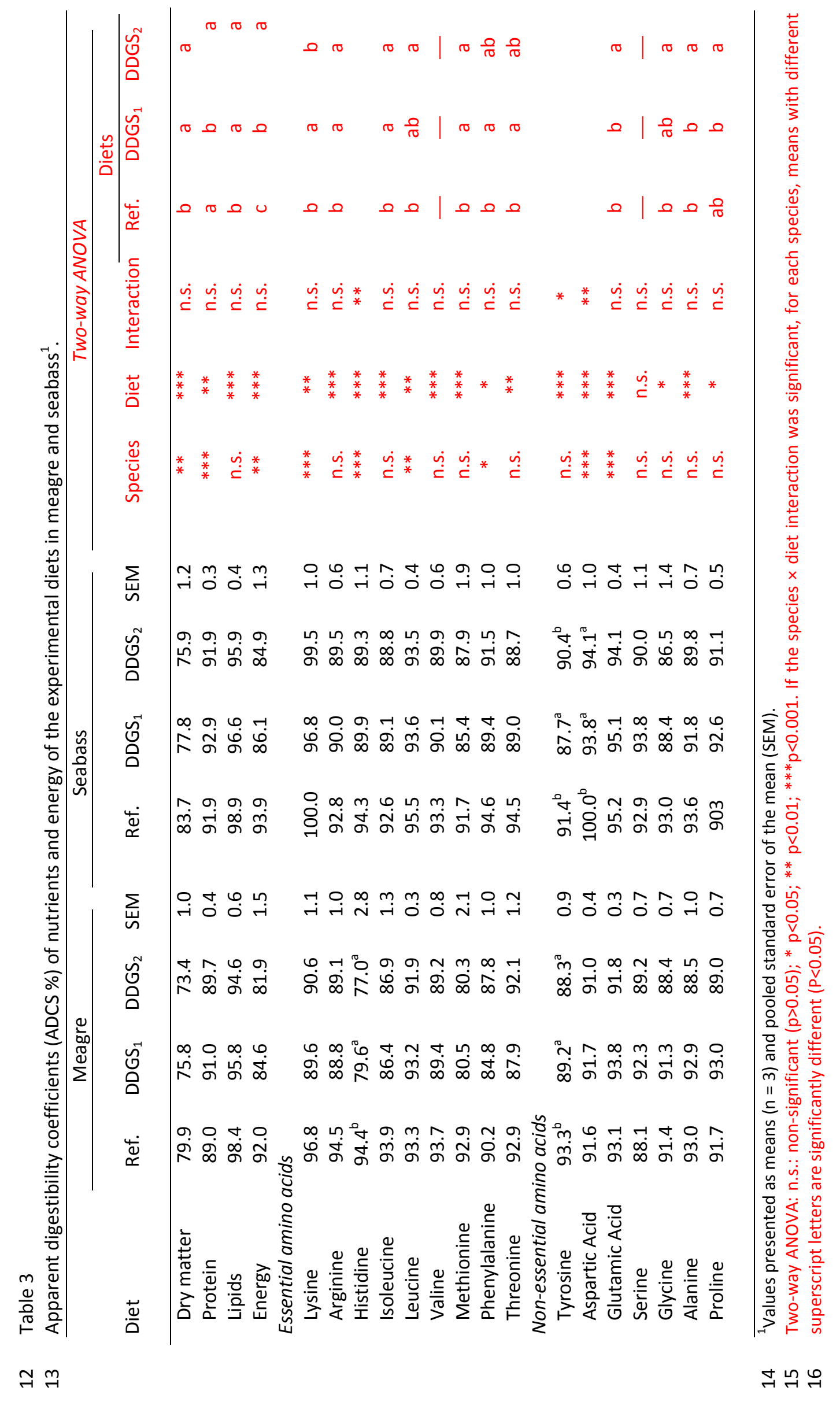




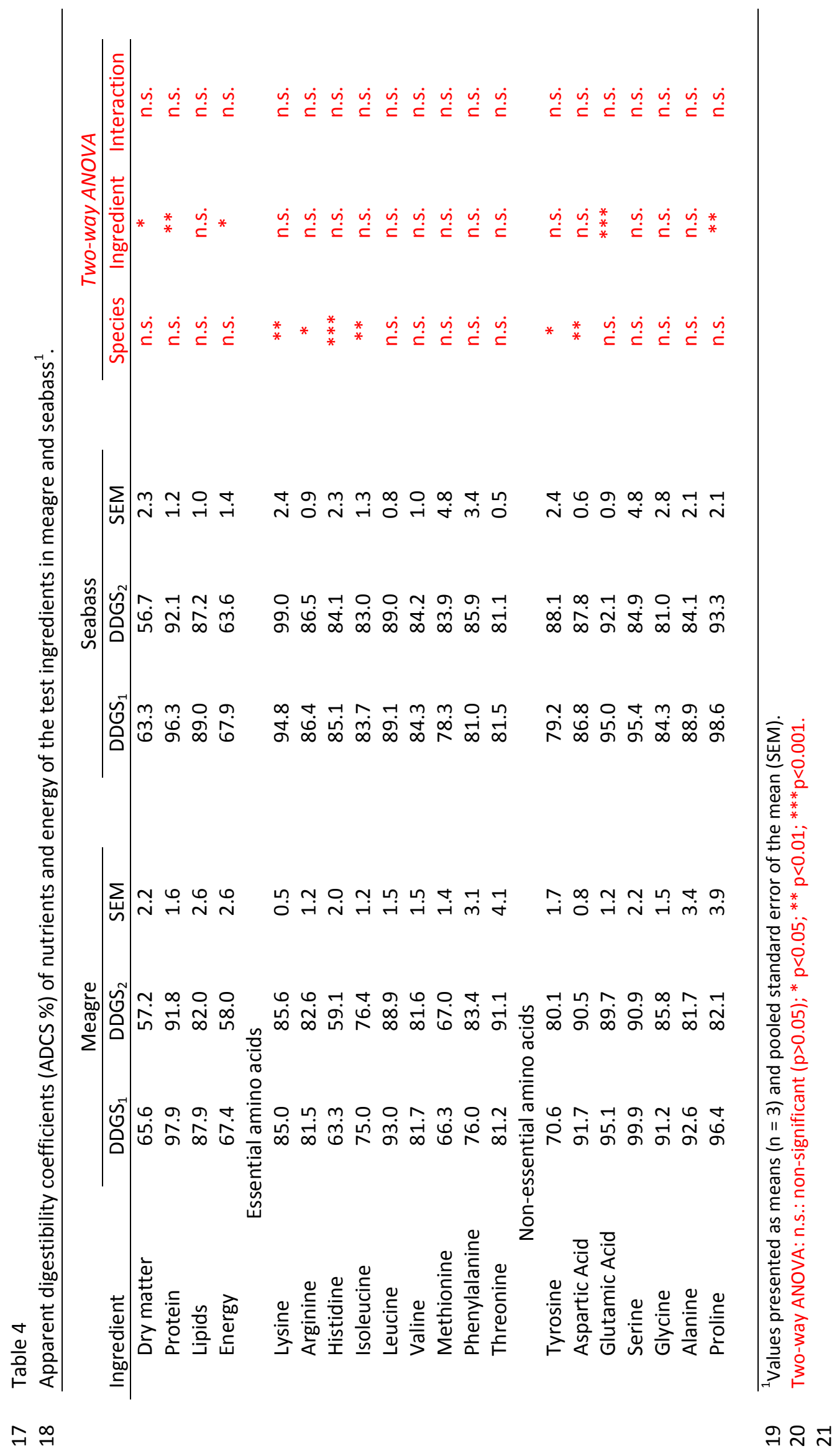




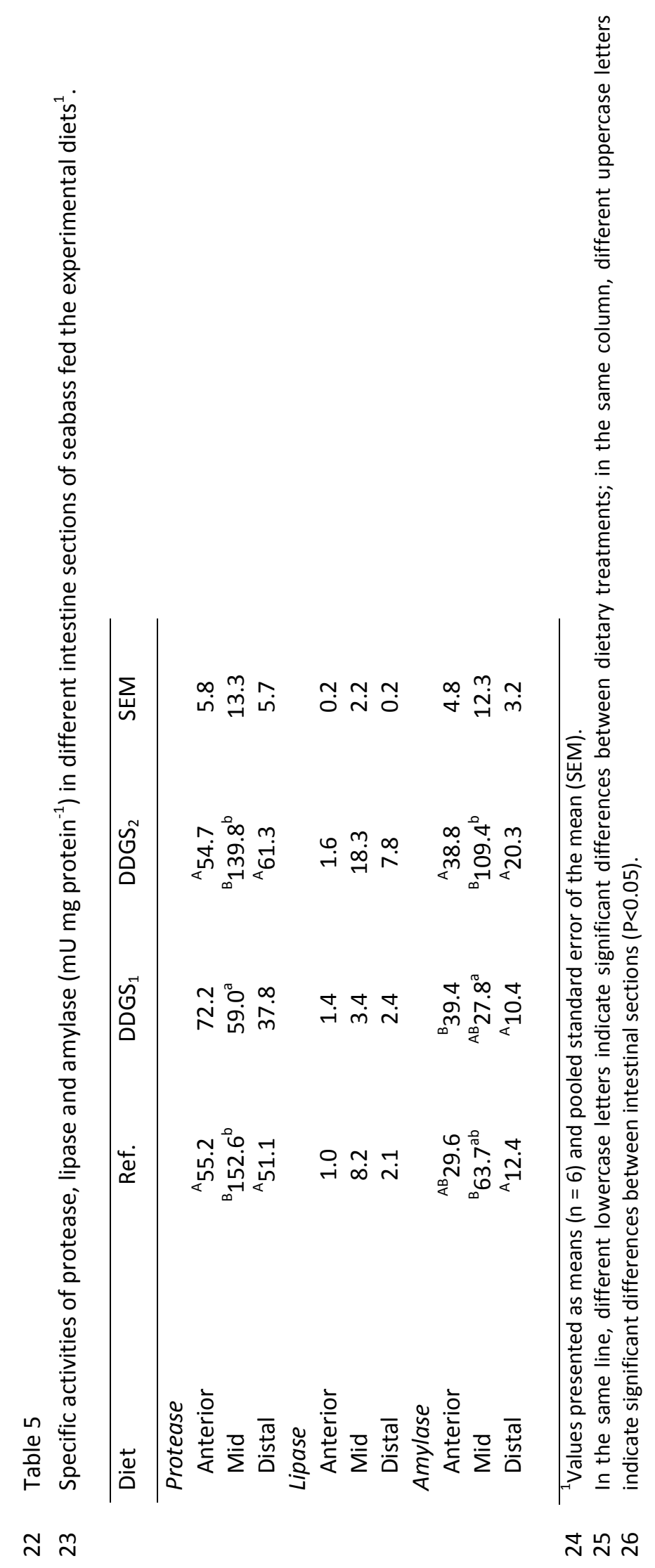




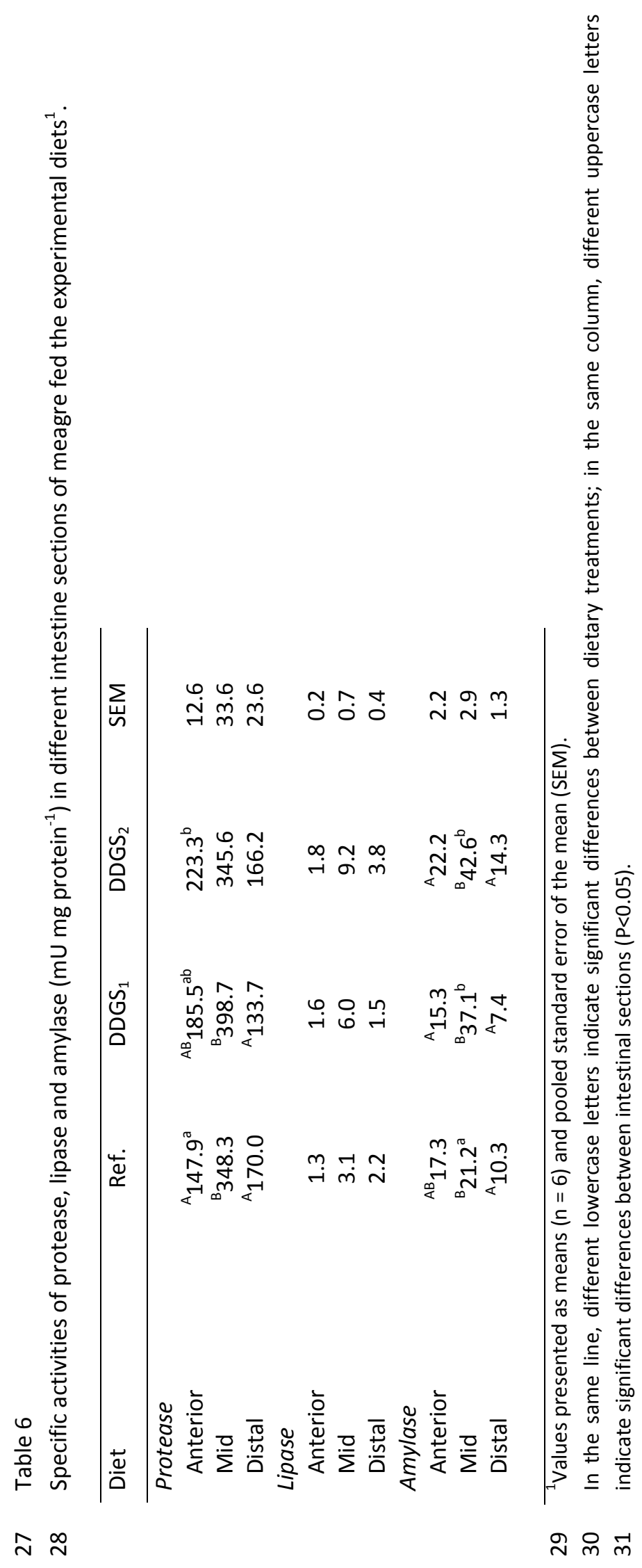




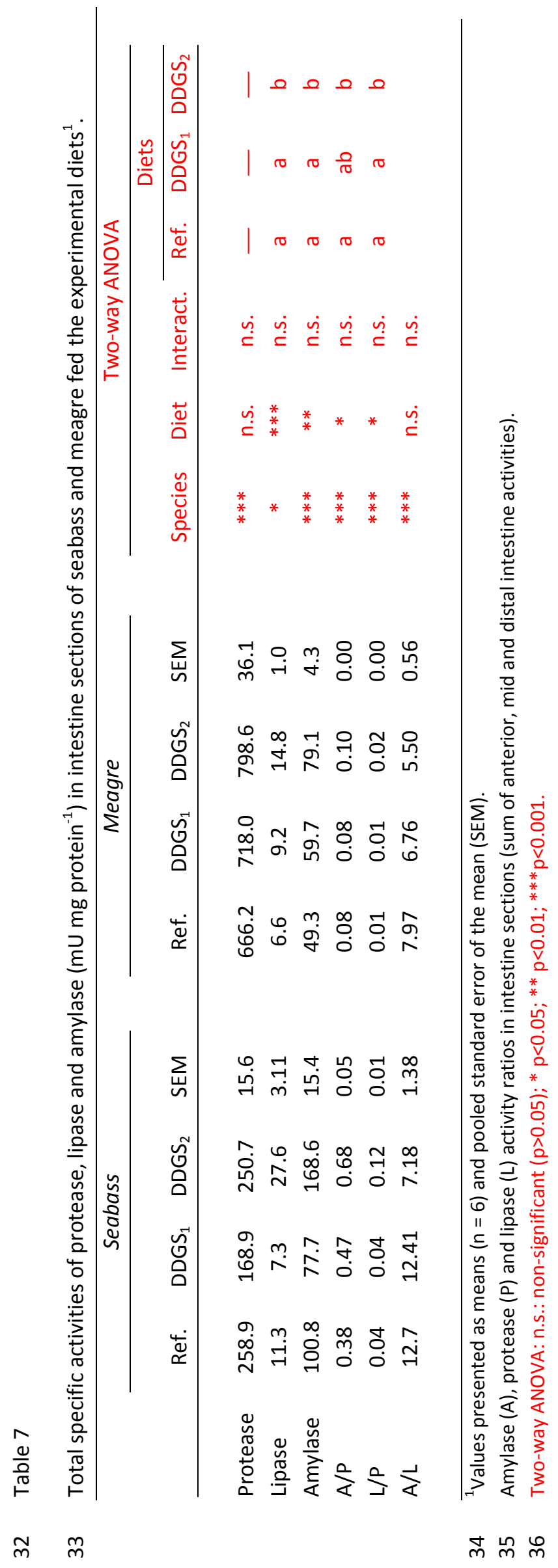

